ISSN: 2617-6548

\title{
Most Common Poisonous Plants of Afghanistan and its Related Clinical Signs in Domestic Animals
}

\author{
Mohammad Monir Tawfeeq ${ }^{1 *}$, Jahid Zabuli, Shahpoor Rahmati \\ ${ }^{1}$ Department of Clinic, Faculty of Veterinary Science, Kabul University, Jamil Mina, Kabul, Afghanistan \\ *Corresponding author: Mohammad Monir Tawfeeq (monir.tawfeeq@gmail.com)
}

\begin{abstract}
Afghanistan is a landlocked country, having high mountains and high percentage (46\%) of permanent pastures. Many types of plants including different species of poisonous grow in the country. Many species of wild and domestic animals have free access to these poisonous plants. In developed countries, poisoning is counted as one of the most important problem for animals, but in Afghanistan it is remained among inconsiderable illness as compared to infectious or metabolic diseases. Yearly, several outbreaks of unknown diseases occur in those areas which are rich of poisonous plants and cause serious economic consequences and human health concerns. The effects of poisonous plants on animals in Afghanistan and its common clinical signs have been remained unrecognized. In this review, we investigate the most common poisonous plants to animals present in Afghanistan and its related clinical signs for early diagnosis of plant poisoning in domestic animals. This review will help readers to distinguish poisonous plants, toxic parts, poisoning signs and the areas where they grow.
\end{abstract}

Keywords: Domestic animals, Poisonous plants, Clinical signs, Outbreaks.

DOI: 10.53894 /ijirss.v3i2.33

Funding: This study received no specific financial support.

History: Received: 9 April 2020/Revised: 4 May 2020/Accepted: 22 May 2020/Published: 29 May 2020

Licensed: This work is licensed under a Creative Commons Attribution 4.0 License $($ (cc) EY

Acknowledgement: Both authors contributed to the conception and design of the study.

Competing Interests: The authors declare that they have no conflict of interests.

Transparency: The authors confirm that the manuscript is an honest, accurate, and transparent account of the study was reported; that no vital features of the study have been omitted; and that any discrepancies from the study as planned have been explained.

Ethical: This study follows all ethical practices during writing.

\section{Introduction}

Afghanistan is a landlocked mountainous country encircled by Pakistan to the east and south, Iran to the west, Turkmenistan, Uzbekistan, and Tajikistan to the north, and China to the northeast [1]. In Afghanistan, most of the people are engaged in agriculture and animal husbandry. Among the total areas of Afghanistan; the arable area is $12 \%, 3 \%$ forest, $46 \%$ is permanent pasture and the remaining is counted for mountains. Mostly, all the people who are engaged in agriculture keep animals for their daily expenses. The wide areas of permanent pasture provide good sources for animal husbandry [2]. Afghanistan is home of 5.3 million cattle, 13.2 million sheep, 7.7 million goats, 0.17 million camels, 0.171 million horse, 1.45 
million donkeys and 11.9 million of chicken. Different species of wild animals are also reported in Afghanistan that play key role in economy [2].

Different kinds of plants have been recognized in Afghanista [3], including several species of poisonous plants. Poisonous plants cause severe economic losses to farmers as well as it consequences concerns for human health [4]. Poisoning counted as one of the serious problem for animals; but in Afghanistan it has remained among inconsiderable illness as compared to infectious or metabolic diseases. Several factors can be counted for this hypothesis such as lack of information regarding poisonous plants and their effects. However, most of the poisonous plants are bitter and unpalatable, but sometimes like lack of food or drought or mixed into forage and eaten by animals, cause poisoning. In Afghanistan, most of the animals especially sheep, goats, and camels are kept by nomads who travel in different seasons of the year to the different parts of the country. Such animals graze and eat different types of plants including poisonous one. The purpose of this review is to introduce the most common toxic plants existed in Afghanistan which can cause severe mortalities among animals and human health concerns. Common clinical signs of poisoned animals have also been covered. The plants which have been introduced in this article, had been searched from many different reliable sources such as books and articles published nationally or internationally.

\section{Most Common Toxic Plants}

\subsection{Bracken fern}

Bracken (Pteridium aquilinum) is one of the most common poisonous plants Figure1, A which is widely distributed in the world including Europe, South, and Central America and Southeast Asia. Poisoning by bracken has been reported in ruminant, non-ruminant as well as human [5-7]. Bracken is a fern belonging to the Dennstaedtiaceae family and consists of subspecies [8, 9], that has been recognized in several parts of Afghanistan [4]. Eating of this plant or its extract can cause poisoning in animals. Fern contains toxic materials like cyanogenetic glycoside, thiaminase and other important chemical compounds that can cause anemia, hematuria, and neoplasia that leads sever production losses [10]. The toxin in the fern named Pataquiloside is carcinogenic and cause bladder neoplasia, aplastic anemia, and hemorrhage. In non-ruminant like horses, it causes thiaminase depletion [11]. Carcinoma of digestive and urinary systems reported due to ingestion of fern by cattle [12,13]. Chronic ingestion of fern leads to Enzootic hematuria [14], anemia, and increased body temperature, blindness [15], decreased bodyweight, ataxia, and recumbency. The untreated animal dies within a few days from showing clinical signs [16].

\subsection{Calotropis procera}

Calotropis procera (Figure1) is found in some parts of Afghanistan [4]. Calotropis is an organic irritant and poisonous contains active principles such as Uscharin, Calacatin and Calotoxin [17]. Calotropis gigantea and calotropis procera are the subspecies of calotropis which belong to the family of Asclepiadaceae. The milky juice of calotropis procera is more toxic than calotropis gigantea. All parts of this plant including the root, stem, and leaves are toxic [18]. The animal can be affected by different ways like ingestion of plants or direct injection of its products. Affected animals shows the clinical signs inflammation of the gastrointestinal tract, diarrhea, dehydration, and cardiac arrhythmias. The cardiac arrest also seen in animals due to the ingestion of calotropis [14].

\subsection{Datura}

Datura commonly known as thorn apple is the plant belongs to the family of Solanaceae. Datura has different species, all of them are poisonous to animals. Different species of Datura (Datura stramonium, Datura metaloides, Datura arborea, and other species) have been recognized[19]. Some species of datura are present in Afghanistan such as Datura fastuosa, Datura innoxia (Figure1) and Datura stramonium (Figure1) [4]. Datura is regarded to be toxic to different species of animals especially horses. Datura is also toxic to humans and contains tropane alkaloids like hyoscyamine, scopolamine, and atropine [20]. Datura alkaloid's work as anticholinergic and cause parasympatholytic action in animal, because they are counted as antagonists of acetylcholine receptors. After ingestion of feed by animals the Datura alkaloids are absorbed and as a result, gastrointestinal complications or death may occur[20]. Animals poisoned by Datura commonly show clinical signs like thirst, mydirais and visual disorders such as blindness. Respiratory paralysis, ataxia, and dry mucus membranes are other clinical signs in animals [21].

\subsection{Ricinus communis}

Ricinus communis (Figure1) poisoning caused by toxic principles of castor beans which is mostly found in temperate countries. The product of this plant (oil) is mostly used as antihelmintic and laxative. The castor oil itself is not toxic, because it does not have ricin. The cake of ricinus communis contains lectins like ricin 1 and ricin 2, which is the most powerful phytotoxin. Ricin 2 is more toxic. Wide variation in the lethal dose of ricin in different species of animals have been reported [22]. After ingestion of cake or beans of castor, poisoning occur. All animals are susceptible to ricin toxicity, the horse is more than all [4]. Ricinus communis is found in some parts of Afghanistan that animal has free access to them [4]. Affected animals commonly show the clinical signs weakness, profuse watery diarrhea, dehydration with sunken eyes, and dilation of pupils, 
depression, tachycardia, dyspnoea, and colic, that develop within 6-24 h after ingestion of ricin [23]. Vomiting, diarrhea, bloody diarrhea and abdominal pain can also be seen[24].

\subsection{Locoweed}

Locoweed poisoning is one of the major concerns in the Western United States and mostly widespread plant in that region. Poisoning is caused by the ingestion of some poisonous species of this plant called Astragalus and Oxytorpis [25]. Several hundred species of these plants are existed. The toxic species is divided into three categories such as selenium-containing, nitrotoxin containing and loccoism containing plants. The existed toxin in these plants is named Swinsonine that was recognized in Australia. Swainsonine interferes with the activities of a cellular enzyme called mannosidases, which help in the processing of oligosaccharides and glycoproteins [26]. Several species (toxic and non-toxic) of Astragalus and Oxytropis that cause locoweed poisoning in animals have been recognized in different parts of Afghanistan [4] (Table 1). Animals that poisoned by locoweed mostly show subclinical and chronic sings of diseases like anorexia, emaciation, fertility disorders, changing of animal behavior, depression, cardiovascular disorders, and nervous sings, variation in the clinical signs among animals can also be seen [27].

\subsection{Nerium Oleander}

Nerium oleander (Nerium indicum) is a poisonous plant (Figure1) belonging to the family of Apocynaceae with narrow and long leaves. This plant is found in many countries including USA, Mediterranean areas [28] as well as in some parts of Afghanistan [4]. All parts of the plant are poisonous to humans and animals. Nerium indicum contains cardiac glycosides named oleandrin, digitoxigenin, neriin, folinerin, and rosagenin [19, 29]. Inhalation smoke of burned plant or ingestion of this plant or its extract can cause severe effects on the body [29, 30]. Poisoned animals show clinical signs of sever inflammation of the digestive system, abdominal pain, sweating, and weakness. These sings occur immediately after ingestion of the plant. Cardiac disorder like arrhythmias is another sign of Nerium indicum poisoning [19].

\subsection{Aconitum}

Different species of Aconitum plant have been recognized in the world [29]. Among them, Aconitum rotundifolium (Figure1) have been observed in different parts of Afghanistan (Table-1) [4]. All parts of Aconitum especially the roots and leaves are toxic[31]. Animals poisoned by Aconitum show clinical signs of central nervous systems disorders, abnormalities in digestive systems like gastroenteritis and abdominal pain, the animal may die due to the development of cardiac abnormalities[32]. Hypotension, depression, conduction disturbance, tachycardia are other signs that are observed in poisoned animals [33].

\subsection{Adonis}

Different species of Adonis like Adonis Aestivalis, A. scrobiculata and A. Turkestanica (Figure1) are existed in different parts of Afghanistan Table 1 [4], belonging to Ranuculaceae family, which is unpalatable. Poisoning of animals by this plant has been reported in horses [34], pigs [35] and sheep [36]. Adonis species contain glycosides resembling digitalis and other toxins present in oleander [37]. Clinical signs of Adonis poisoning in animals, especially in horses include disorders of the gastrointestinal tract, abdominal pain, bloody diarrhea and decreased gut motility [37]. The severity of clinical signs depends on the amount of ingested plant [29].

Several other toxic plants which are not very common are also exist in different parts of Afghanistan. Their names, family names, local names, toxic parts, toxic materials, clinical signs and places which grow in Afghanistan are listed in Table 1. 

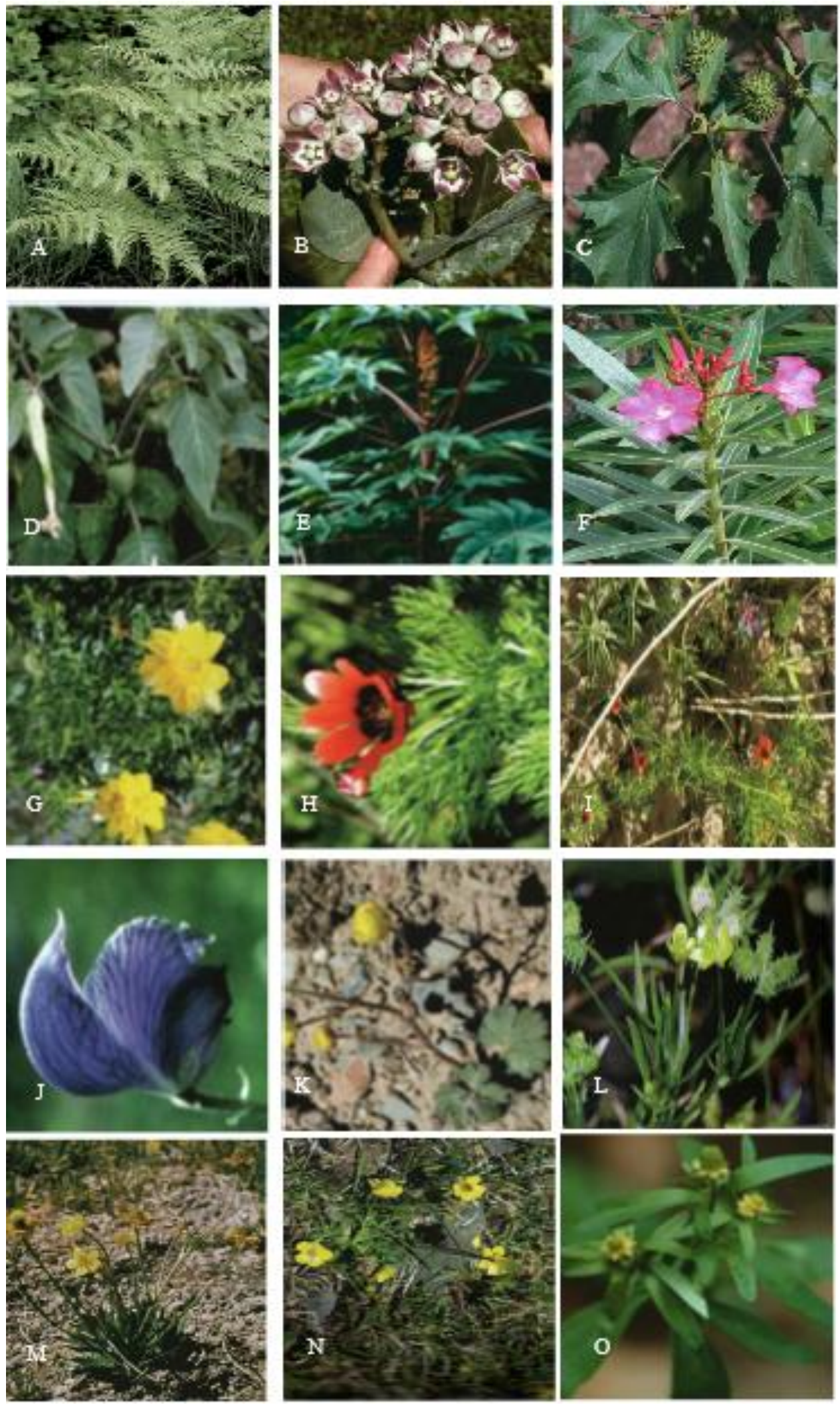

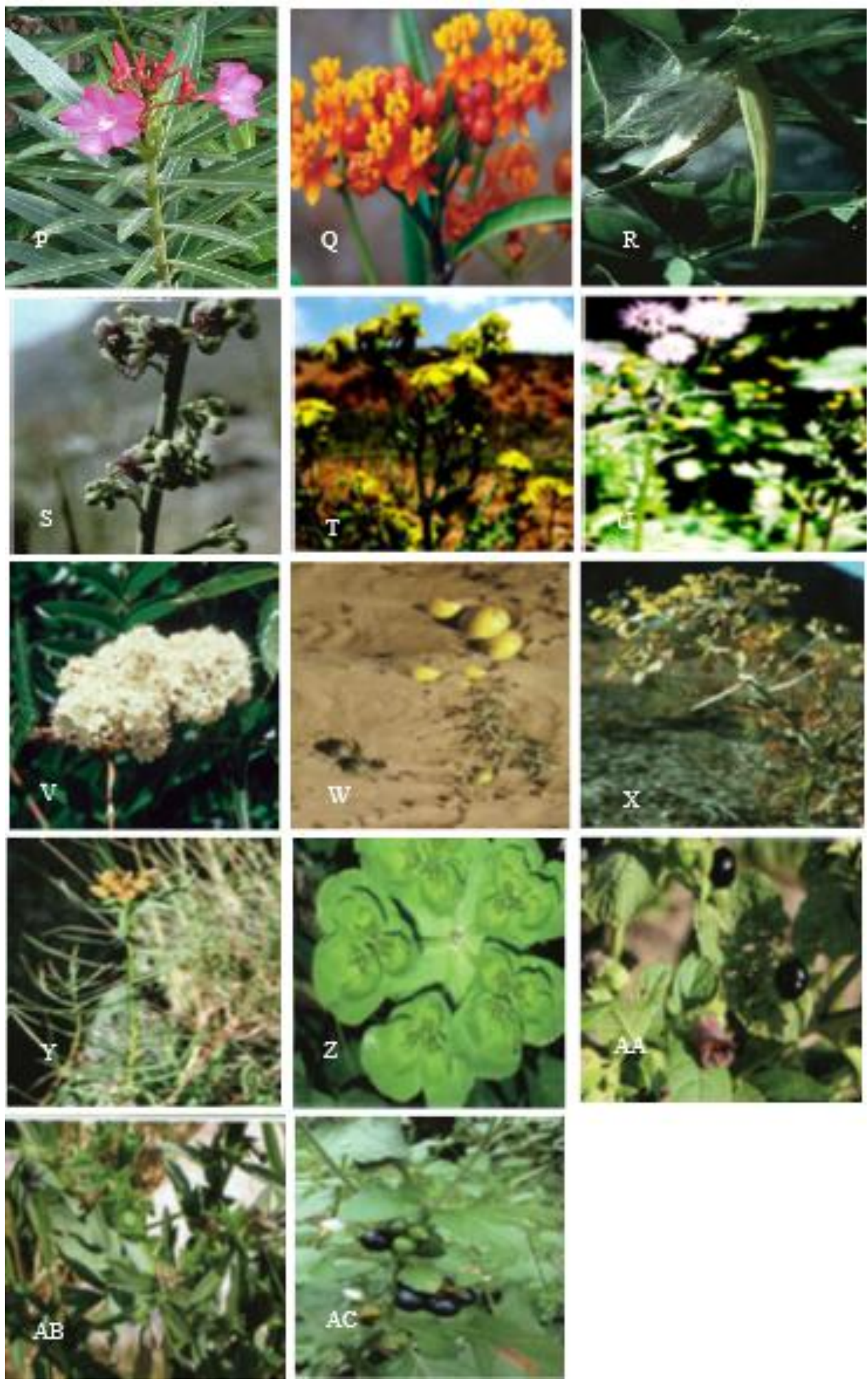

\section{Figure-1.}

Photos of the poisonous plants that can be found in Afghanistan. A: Pteridium aquilinum, B: Calotropis procera, C: Datura innoxia, D: D. stramonium, E: Ricinus communis, F: Nerium indicum, G: Aconitum rotundifolium, H: Adonis aestivalis, I: A. scrobiculata. J: A. turkestanicus, K: Ranunculus afghanicus, L: $R$. arvensis, M: $R$. longicaulis, $\mathrm{N}: R$. pulchellus, $\mathrm{O}: R$. sceleratus, $\mathrm{P}$ : Catharanthus roseus, Q: Asclepias curassavica, R: Cynanchum acutum, S: Periploca aphylla, T: Senecio glaucus, U: S. vulgaris, V: Sambucus wightiana, W: Citrullus colocynthis, X: Euphorbia boissieriana, Y: E. cyrtophylla, Z: E. helioscopia, AA: Atropa acuminata, AB: Hyoscyamus niger, AC: Solanum nigrum [4, 29, 38, 39]. 
Table-1.

List of poisonous plants present in Afghanistan, there places they grown, its toxins present in the plant, toxic parts of the plant and their local names[4].

\begin{tabular}{|c|c|c|c|c|c|c|c|}
\hline No & Toxic plants* & Family & Places * & $\begin{array}{l}\text { Local } \\
\text { name* }\end{array}$ & Toxins & Toxic part & Common clinical signs \\
\hline 1 & Pteridium aquilinum (Figure1) & Polypodiaceae & NUR & NA & Ptaquiloside & All parts $[40]$ & $\begin{array}{l}\text { Anemia, hematuria, neoplasia, } \\
\text { hemorrhage, decreased body } \\
\text { weight, ataxia, enzootic } \\
\text { hematuria and blindness [10- } \\
\text { 16]. }\end{array}$ \\
\hline 2 & Calotropis procera (Figure1) & Asclepiadaceae & $\mathrm{E}, \mathrm{SE}$ & Spelmai & Alkaloids & All parts $[41]$ & $\begin{array}{l}\text { Dehydration, diarrhea, cardiac } \\
\text { arrhythmias and inflammation } \\
\text { of gastrointestinal tract, [14]. }\end{array}$ \\
\hline 3 & $\begin{array}{l}\text { Datura innoxia (Figure1) } \\
\text { D. stramonium (Figure1) }\end{array}$ & Solanaceae & $\begin{array}{l}\text { NE, C } \\
\text { NW, SE, E, }\end{array}$ & Datura & Alkaloids & All parts [20] & $\begin{array}{l}\text { Thirst, mydriasis, blindness, } \\
\text { respiratory paralysis, ataxia, } \\
\text { and dry mucus membranes } \\
{[21] \text {. }}\end{array}$ \\
\hline 4 & Ricinus communis (Figure 1 ) & Euphorbiaceae & SW, Hari Rud, JLB & $\begin{array}{l}\text { Nabat-e } \\
\text { Kastror } \\
\text { oil }\end{array}$ & Ricin & $\begin{array}{l}\text { Seeds } \quad[42, \\
43]\end{array}$ & $\begin{array}{l}\text { Weakness, sunken eye, watery } \\
\text { diarrhea, depression, } \\
\text { tachycardia and vomiting [24]. }\end{array}$ \\
\hline 5 & Nerium indicum (Figure1) & Apocynaceae & $\mathrm{E}$ & $\begin{array}{l}\text { Gul-e } \\
\text { Gandiri }\end{array}$ & Oleandrin & All parts[44] & $\begin{array}{l}\text { Bradycardia and ventricular } \\
\text { fibrillation [45]. }\end{array}$ \\
\hline 6 & Aconitum rotundifolium (Figure1) & Ranunculaceae & $\mathrm{E}, \mathrm{NE}$ & NA & Alkaloids & Root [46] & $\begin{array}{l}\text { Weakness, ataxia, respiratory } \\
\text { distress and diarrhea[47]. }\end{array}$ \\
\hline 7 & $\begin{array}{l}\text { Adonis aestivalis (Figure1) } \\
\text { A. scrobiculata (Figure1) } \\
\text { A. turkestanicus (Figure1) }\end{array}$ & Ranunculaceae & $\begin{array}{l}\text { SW, SE, E, NE } \\
\text { All Parts of AFG } \\
\text { NE }\end{array}$ & NA & $\begin{array}{l}\text { Cardiac } \\
\text { glycosides }\end{array}$ & All part $[48]$ & $\begin{array}{l}\text { Abdominal pain, bloody } \\
\text { diarrhea, decrease gut motility } \\
\text { and cardiac arrhythmias [29, } \\
\text { 37]. }\end{array}$ \\
\hline 8 & $\begin{array}{l}\text { Ranunculus afghanicus (Figure1) } \\
R . \text { arvensis (Figure1) } \\
R . \text { longicaulis (Figure1) } \\
\text { R. pulchellus (Figure1) } \\
\text { R. sceleratus (Figure1 }\end{array}$ & Ranunculaceae & $\begin{array}{l}\text { NW, E, SE, NE, C } \\
\text { NW, SE, NE, SW } \\
\text { E, NE } \\
\text { Wakhan } \\
\text { NW, E, NE }\end{array}$ & NA & Protoanemonin & Sap [49] & $\begin{array}{l}\text { Colic, depression, salivation, } \\
\text { blindness, blood stain urine, } \\
\text { muscle trembling, twitching } \\
\text { and discoloration of cow's milk } \\
\text { [50]. }\end{array}$ \\
\hline 9 & Catharanthus roseus (Figure1) & Apocynaceae & Cultural & NA & Alkaloids & All parts[51] & $\begin{array}{l}\text { Electrolytes imbalance, } \\
\text { dehydration, severe abdominal } \\
\text { pain, profuse diarrhea and } \\
\text { cardiovascular collapse[52]. }\end{array}$ \\
\hline 10 & Asclepias curassavica (Figure1) & Asclepiadaceae & All part of AFG & NA & Cardenolides & All parts[53] & $\begin{array}{l}\text { Vertigo, headache, vomiting, } \\
\text { diarrhea, stomach cramps, and } \\
\text { arrhythmia [54]. }\end{array}$ \\
\hline 11 & Cynanchum acutum (Figure1) & Asclepiadaceae & Most part of AFG & NA & Alkaloids & All part [55] & $\begin{array}{l}\text { Hypersensitivity, } \\
\text { incoordination and central } \\
\text { nervous system disorders have } \\
\text { been reported [56]. }\end{array}$ \\
\hline
\end{tabular}




\begin{tabular}{|c|c|c|c|c|c|c|c|}
\hline 12 & Periploca aphylla (Figure1) & Asclepiadaceae & SW, SE, E & NA & Alkaloids & & $\begin{array}{l}\text { No reports about its clinical } \\
\text { signs of this plant are available }\end{array}$ \\
\hline 13 & $\begin{array}{l}\text { Senecio glaucus (Figure1) } \\
\text { Senecio vulgaris (Figure1) }\end{array}$ & Asteraceae & $\begin{array}{l}\text { All regions of S- } \\
\text { Afg- E }\end{array}$ & Pir Kah & Alkaloids & All parts[57] & $\begin{array}{l}\text { Diarrhea, depression, ill thrift, } \\
\text { prolapsed rectum, edema, } \\
\text { ascites and head pressing [58]. }\end{array}$ \\
\hline 14 & Sambucus wightiana (Figure1) & Caprifoliaceae & E, NUR & NA & Glycosides & All parts[29] & $\begin{array}{l}\text { Abdominal pain, lethargy, } \\
\text { sweating and in severe cases } \\
\text { coma and collapse of } \\
\text { cardiovascular occur[29]. }\end{array}$ \\
\hline 15 & Citrullus colocynthis (Figure1) & Cucurbitaceae & SW, S, SE, E & $\begin{array}{l}\text { Tarbooz- } \\
\text { e Abujehl }\end{array}$ & Alkaloids & All parts[59] & $\begin{array}{l}\text { Dullness, ruffled hair, } \\
\text { decreased body weight gains } \\
\text { and feed efficiency reported in } \\
\text { rodent [60]. }\end{array}$ \\
\hline 16 & $\begin{array}{l}\text { Euphorbia boissieriana (Figure1) } \\
\text { E. cyrtophylla (Figure1) } \\
\text { E. helioscopia (Figure1) }\end{array}$ & Euphorbiaceae & $\begin{array}{l}\mathrm{N}, \mathrm{NE}, \mathrm{E}, \mathrm{C} \\
\mathrm{E} \text { (Nuristan) } \\
\text { In most regions, } \\
\text { weed }\end{array}$ & NA & Alkaloids & All parts[59] & $\begin{array}{l}\text { Irritation of the skin and } \\
\text { mucous membranes, visual } \\
\text { disorders and digestive } \\
\text { problems [61]. }\end{array}$ \\
\hline 17 & Atropa acuminata (Figure1) & Solanaceae & $\mathrm{E}$ & NA & Alkaloids & All parts[62] & $\begin{array}{l}\text { Dry mouth, dysphagia, } \\
\text { dysphonia, tachycardia and } \\
\text { urinary retention [29]. }\end{array}$ \\
\hline 18 & Hyoscyamus niger (Figure1) & Solanaceae & $\mathrm{N}, \mathrm{NE}, \mathrm{E}$ & NA & Alkaloids & All parts [63] & $\begin{array}{l}\text { Anorexia, dry muzzle, meiosis } \\
\text { and tenesmus [64]. }\end{array}$ \\
\hline 19 & Solanum nigrum (Figure1) & Solanaceae & NW, SE, E, NE, C & NA & Alkaloids & All parts [30] & $\begin{array}{l}\text { Vomiting, abdominal pain, } \\
\text { nausea and diarrhea [29]. }\end{array}$ \\
\hline
\end{tabular}




\section{Conclusion}

In conclusion, poisoning is counted as one of the most critical problem in animals that can causes severe mortalities. Besides keeping the animals by farmers, most of the animals are kept by nomads in Afghanistan who travel to different parts of the country and access to all kinds of plants that grow in pastures. In this review, we have introduced many types of poisonous plants grow in different parts of Afghanistan, there local names, photos, toxins they have, and toxic parts of the plants. Besides, the clinical signs of poisoned animals which are very important for the veterinarian to diagnose poisoning have been discussed too.

\section{References}

[1] K. Favre, "Watershed atlas of afghanistan, ministry of irrigation," Afghanistan, vol. 1, 2004.

[2] Afghanistan statistical yearbook, pp. 155-175, 2016.

[3] M. H. Amini and S. M. Hamdam, "Medical plants used traditionally in guldara district of kabul, afghanistan," International Journal of pharmacology and Chinese Medicine, vol. 1, pp. 1-13, 2017. Available at: https://doi.org/10.23880/ipcm-16000118.

[4] S. W. Breckle and M. D. Rafiqpoor, "Field guide afghanistan-flora and vegetation, scientia, bonnesnsis," ed New York: BonnManama, 2010, pp. 230-780.

[5] A. Gava, D. da Silva Neves, D. Gava, S. T. de Moura, A. L. Schild, and F. Riet-Correa, "Bracken fern pteridium aquilinum poisoning in cattle in southern Brazil," Veterinary and Human Toxicology, vol. 44, pp. 362-365, 2002.

[6] E. Marrero, C. Bulnes, L. Sanchez, I. Palenzuela, R. Stuart, F. Jacobs, and J. Romero, "Pteridium aquilinum (bracken fern) toxicity in cattle in the humid Chaco of Tarija, Bolivia," Veterinary and Human Toxicology, vol. 43, pp. 156-158, 2001. J. Villalobos-Salazar, A. Meneses, J. L. Rojas, J. Mora, R. E. Porras, and M. V. Herrero, "Bracken derived carcinogens as affecting animal and human health in Costa Rica," n: J.A. Taylor. Ed, Bracken Toxicity and Carcinogenicity as Related to Animal and Human Health, UCW Aberystreyth, pp. 40-51, 1989.

G. C. Driver, "Chemotaxonomy and phytochemical ecology of bracken, Bot," The Journal of the Linnean Society, vol. 73, pp. $35-46,2008$.

[9] A. R. Smith, K. Pryer, E. Schuettpelz, P. Korall, H. Schneider, and P. G. Wolf, "Classification for extant ferns," Taxon, vol. 55, pp. 705-731, 2006.

[10] M. L. Clark, D. G. Harvey, and D. J. Humphreys, "Veterinary toxicology," 2nd ed London: Bailliere Tindal, 1981, pp. 35-37.

[11] M. M. Sebastian, S. I. Baskin, and S. E. Czerwinski, "Renal toxicity. In: R.C. Gupta Ed, Veterinary toxicology: Basic and clinical principles," 2nd ed Elsevier: Sand Diego, CA, 2007, pp. 171-172.

[12] G. Fenwick, "Bracken (Pteridium aquilinum)—toxic effects and toxic constituents," Journal of the Science of Food and Agriculture, vol. 46, pp. 147-173, 1989. Available at: https://doi.org/10.1002/jsfa.2740460204.

[13] B. Smith, "Bracken biology and management," JA Taylor, RT Smith, AIAS Occasional Publication, vol. 40, pp. $227-232,1990$.

[14] M. C. Sharma, M. Kumar, and R. D. Sharma, "Textbook of clinical veterinary medicine, Indian council of agricultural research," Delhi, p. 523, 2013.

[15] D. G. Pugh, "Sheep and goat medicine," ed Saunders: Philadelphia, 2002, pp. 307-336.

[16] J. D. Roder, "Veterinary toxicology: The practical veterinarian," ed Woburn, MA: Butterworth-Heinemann, 2001, pp. 103285.

[17] P. C. Sharma, M. B. Yelne, and T. J. Denis, "Data base on medicinal plants used in ayurveda," Divison Central Council for Research in Ayurveda E Siddha, pp. 139-145, 2001.

[18] A. Shanker, "Hand book of poisoning, bgalani publishing house," 2nd ed, 2005, p. 736.

[19] A. Anadon, M. R. M. Larranaga, and V. Castellano, "Poisonous plants of europe. In: R.C. Gupta, E.d.Veterinary toxicology: Basic and clinical principles," 2nd ed Elsevier: Sand Diego, CA, 2012, pp. 1086-1094.

[20] T. W. Naude, "Datura spp. And other related plants. In: R. C. Gupta, Ed, Veterinary toxicology: basic and clinical principles," 1st ed Elsevier: Sand Diego CA, 2007, pp. 895-905.

[21] J. A. Pickrell, F. Oehme, and S. A. Mannala, "Tropane alkaloids in: K. Plumle, ed, clinical veterinary toxicology," 1 st ed Mosby, Inc, 2004, pp. 381-3820.

[22] R. A. Greenfield, B. R. Brown, J. J. Iandolo, and J. B. Hutchins, "Microbiological, biological and chemical weapons of warfare and terrorism," The American Journal of the Medical Sciences, vol. 323, pp. 326-340, 2002.

[23] M. R. Aslani, M. Maleki, M. Mohri, K. Sharifi, Najjar-Nezhad, and E. Afshari, "Castor bean (Ricinus communis) toxicosis in a sheep flock, toxicon," vol. 4, pp. 400-406, 2007.

[24] J. C. Albretsen, S. M. Gwaltney-Brant, and S. A. Khan, "Evaluation of castor bean toxicosis in dogs: 98 cases," J. Am. Anim. Hosp. Assoc, vol. 36, pp. 229-233, 2000. Available at: https://doi.org/10.5326/15473317-36-3-229.

[25] M. H. Ralphs and B. L. Stegelmeier, "Locoweed toxicity, ecology, control, and management," International J. Poison. Plant Res, vol. 1, pp. 47-64, 2011.

[26] D. Cook, M. Ralphs, K. Welch, and B. Stegelmeier, "Locoweed poisoning in livestock," Rangelands, vol. 31, pp. 16-21, 2009. Available at: https://doi.org/10.2458/azu_rangelands_v31i1_cook.

[27] W. Chenchen, W. Wenlong, L. Xiaoxue, M. Feng, C. Dandan, Y. Xiaowen, W. Shanshan, G. Pengshuai, and L. Hao Baoyu, "Pathogenesis and preventive treatment for animal disease due to locoweed poisoning," Environmental Toxicology and Pharmacology, vol. 37, pp. 336-347, 2014. Available at: https://doi.org/10.1016/j.etap.2013.11.013.

[28] J. Meuninck, "Basic illustrated poisonous and psychoactive plants," Morris Book Publishing, LLC, p. 55, 2014. 
[29] L. S. Nelson, R. D. Shih, and M. J. Balick, "Handbook of poisonous and injurious plant," 2nd ed New York: Springer, 2007, pp. 55-274.

[30] S. D. Langford and P. J. Boor, "Oleander toxicity: An examination of human and animal toxic exposures," Toxicology, vol. 109, pp. 1-13, 1996. Available at: https://doi.org/10.1016/0300-483x(95)03296-r.

[31] L. S. Ding, F. E. Wu, and Y. Z. Chen, "Diterpenoid alkaloids from Aconitum gymnandrum," Yao Xue Xue Bao, vol. 28, pp. 188-191, 1993.

[32] C. C. Lin, T. Y. Chan, and J. F. Deng, "Clinical features and management of herb-induced aconitine poisoning," Ann Emerg Med, vol. 43, pp. 574-579, 2004.

[33] C. K. Zoltani, "Cardiovascular toxicity. In: R.C. Gupta, Ed, Veterinary toxicology: Basic and clinical principles," 2nd ed Elsevier: Sand Diego, CA, 2012, p. 238.

[34] L. W. Woods, M. S. Filigenzi, M. C. Booth, L. D. Rodger, J. S. Arnold, and B. Puschner, "Summer pheasant's eye (Adonis aestivalis) poisoning in three horses," Vet Pathol, vol. 41, pp. 215-220, 2004. Available at: https://doi.org/10.1354/vp.41-3215.

[35] R. Davies and P. Whyte, "Adonis microcarpa (pheasant's eye) toxicity in pigs fed field pea screenings," Australian Veterinary Journal, vol. 66, pp. 141-143, 1989. Available at: https://doi.org/10.1111/j.1751-0813.1989.tbo9780.x.

[36] E. Hurst, "The poison plants of New South Wales, New South Wales poison plants committee," Sidney, Australia, pp. 113$114,1942$.

[37] B. Puschner, A. Peters, and L. Woods, "Toxic weeds and their impact on animals," 2006.

[38] S. W. Breckle, I. C. Hedge, and M. D. Rafiqpoor, Vascular plants of afghanistan: An augmented checklist, scientia. Bonn-ManamaNew York: Bonnesnsis, 2013.

[39] A. P. Knight, "A guide to poisonous house and garden plants," Teton NewMedia, Jackson, W, Y, vol. 42, pp. 57-155, 2007.

[40] J. Vetter, "A biological hazard of our age: Bracken fern [Pteridium aquilinum (L.) Kuhn]—A review," Acta Veterinaria Hungarica, vol. 57, pp. 183-196, 2009. Available at: https://doi.org/10.1556/avet.57.2009.1.18.

[41] T. Divya, W. Rakesh, D. Kuldip, and S. Priya, "Review on calotropis gigantea," IJPPR, vol. 13, pp. 125-134, 2018.

[42] A. S. Loannidis, K. Papageorgiou, and P. S. Andreou, "Exposure to Euphorbia lathyris latex resulting in alkaline chemical injury: a case report," J. Medical Case Reports2009.

[43] T. Akande, A. Odunsi, and E. Akinfala, "A review of nutritional and toxicological implications of castor bean (Ricinus communis L.) meal in animal feeding systems," Journal of Animal Physiology and Animal Nutrition, vol. 100, pp. $201-210,2016$. Available at: https://doi.org/10.1111/jpn.12360.

[44] P. Day and T. K. Chaudhuri, "Pharmacological aspects of nerium indicum mill a comprehensive review," Pharmacogn Rev, vol. 8, pp. 156-162, 2014. Available at: https://doi.org/10.4103/0973-7847.134250.

[45] C. K. Zoltani, "Cardiovascular toxicity. In: R.C. Gupta, Ed, Veterinary toxicology: Basic and clinical principles," 2nd ed Elsevier: Sand Diego, CA, 2007, pp. 236-37.

[46] T. Chen, "Aconie poisoning," Clin toxicol, vol. 47, pp. 279-285, 2009.

[47] B. Puschner, M. C. Booth, E. R. Tor, and A. Odermatt, "Delphinium alkaloid toxicosis in cattle from switzerland. In: T. Acamovic., C.S. Stewart, and T. W. Pennycott, Eds, poisonous plant and related toxins," ed Wallingford, UK: CABI Publishing, 2004, pp. 37-42.

[48] L. W. Woods, L. W. George, M. L. Anderson, D. M. Woods, M. S. Filigenzi, and B. Puschner, "Evaluation of the toxicity of Adonis aestivalis in calves," Journal of Veterinary Diagnostic Investigation, vol. 19, pp. 581-585, 2007. Available at: https://doi.org/10.1177/104063870701900523.

[49] R. Cope and K. K. Parton, "Poisonous plants of Australia and New Zealand. In: R.C. Gupta, Ed, Veterinary toxicology: basic and clinical principles," 2nd ed Elsevier: Sand Diego, CA, 2012, pp. 1101-1104.

[50] V. Beasly, "Plants that affect the gastrointestinal tract (Part I)," In: V. Beasly Ed, Veterinary Toxicology, pp. 532-555, 1999.

[51] J. N. Mishra and N. K. Verma, "A brief study on Catharanthus roseus: A review," Intern J Res Pharmacy Pharmaceut Sci, vol. 2, pp. 20-23, 2017.

[52] A. C. Barr, "IHoushold and garden plants. In: M. E. Peterson and P.A. Talcott, Eds, small animal toxicology," in elsevier, 3rd ed Sounders, St. Louis, Missouri, 2013, p. 374.

[53] A. E. A. I. Snafi, "Chemical constituents and pharmacological effects of asclepias curassavica - a review," Asian J. Pharm. Res, vol. 5, pp. 83-87, 2015.

[54] M. Huang, S. Shen, C. Luo, and Y. Ren, "Genus Periploca (Apocynaceae): A review of its classification, phytochemistry, biological activities and toxicology," Molecules, vol. 24, p. 2749, 2019. Available at: https://doi.org/10.3390/molecules24152749.

[55] A. M. M. Youssef, Z. A. S. E. L. Swaify, Y. M. A. L. Saraireh, and S. M. A. L. Dalain, "Cytotoxic activity of methanol extract of Cynanchum acutum L. seeds on human cancer cell lines," Lat. Am. J. Pharm, vol. 10, pp. 1997-2003, 2018.

[56] C. J. Botha, "Christoffel jacobus," Venter, Elna; Cynanchum Species, 2002.

[57] W. Panziera, S. P. Pavarini, L. Sonne, C. S. Barros, and D. Driemeier, "Poisoning of cattle by Senecio spp. in Brazil: A review," Pesquisa Veterinária Brasileira, vol. 38, pp. 1459-1470, 2018. Available at: https://doi.org/10.1590/1678-5150-pvb5795. 
[58] K. E. Panter, K. D. Welch, D. R. Gardner, S. T. Lee, B. T. Green, J. A. Pfister, D. Cook, T. Z. Davis, and B. L. Stegelmeier, "Poisonous plants of the United States. In: R.C. Gupta, Ed, Veterinary toxicology: Basic and clinical principles," 2nd ed Elsevier: Sand Diego, CA, 2007, p. 1063.

[59] M. Rezvani, M. Hassanpour, M. Khodashenas, G. Naseh, M. Abdollahi, and O. Mehrpour, "Citrullus colocynthis (bitter apple) poisoning," A Case Report. Indian Journal of Forensic Medicineङ Toxicology, vol. 2, pp. 25-27, 2011.

[60] M. Al-Yahya, A. Al-Farhan, and S. Adam, "Preliminary toxicity study on the individual and combined effects of Citrullus colocynthis and Nerium oleander in rats," Fitoterapia, vol. 71, pp. 385-391, 2000. Available at: https://doi.org/10.1016/s0367-326x(00)00135-0.

[61] G. E. Burrows and R. J. Tyrl, "Toxic plants of North America," 2nd ed Iowa State: Wiley- Blackwell, 2013 , p. 464.

[62] S. Worbs, K. Köhler, D. Pauly, M.-A. Avondet, M. Schaer, M. B. Dorner, and B. G. Dorner, "Ricinus communis intoxications in human and veterinary medicine-a summary of real cases," Toxins, vol. 3, pp. 1332-1372, 2011. Available at: https://doi.org/10.3390/toxins3101332.

[63] M. A. Berdai, S. Labib, K. Chetouani, and M. Harandou, "Atropa belladonna intoxication: A case report," Pan. Afr. Med. J, vol. 11, p. 72, 2012.

[64] V. Naidoo, "Datura species and related plants. In: R.C. Gupta, Ed, Veterinary toxicology: Basic and clinical principles," 2nd ed Elsevier: Sand Diego, CA, 2007, p. 1152. 